\title{
New palaeoclimate reconstructions based on multidisciplinary investigation in the Ferdynandów 2011 stratotype site (eastern Poland)
}

\author{
Renata STACHOWICZ-RYBKA ${ }^{1, *}$, Irena Agnieszka PIDEK ${ }^{2}$ and Marcin ŻARSKI ${ }^{3}$ \\ 1 W. Szafer Institute of Botany, Polish Academy of Sciences, Lubicz 46, 31-512 Kraków, Poland \\ 2 Maria Curie-Skłodowska University, Faculty of Earth Sciences and Spatial Management, Kraśnicka 2c/d, \\ 20-718 Lublin, Poland \\ 3 Polish Geological Institute - National Research Institute, Rakowiecka 4, 00-975 Warszawa, Poland
}

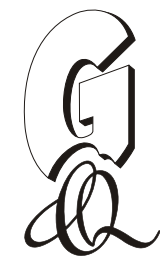

Stachowicz-Rybka, R., Pidek, I.A., Żarski, M., 2017. New palaeoclimate reconstructions based on multidisciplinary investigation in the Ferdynandów 2011 stratotype site (eastern Poland). Geological Quarterly, 61 (2): 276-290, doi: 10.7306/gq.1353

Drilling carried out in 2011 at Ferdynandów (E Poland), serving as a stratotype for the Ferdynandovian Interglacial, enabled its re-examination with high-resolution palynological, plant macroremains, and sedimentological analyses. Lacustrine sediments included a record of the Late Sanian 1 (= Elsterian 1) Glaciation, a complete Ferdynandovian succession, and the Early Sanian 2 (= Elsterian 2) Glaciation. Particular similarities in the succession observed between the Ferdynandów 2011 profile and the adjacent sites of the same age in Łuków-3A and Zdany provide a basis for detailed palaeoclimate interpretation. The Ferdynandovian succession of all the three pollen profiles can be clearly divided into two distinct interglacials separated by a sequence of pollen spectra typical of a glacial succession with pollen zones of stadial-interstadial fluctuations. Warm units in the Ferdynandów 2011 succession correspond to climatostratigraphic units of Ferdynandovian 1 and 2, while the cold unit - to Ferdynandovian 1/2. This division can be applied to all Ferdynandovian successions in Poland and allows their correlation with the early Middle Pleistocene Cromerian Complex of Western Europe (Cromerian II Westerhoven and Cromerian III Rosmalen) as well as with Marine Isotope Stages (MIS) 13-15. For each biostratigraphic unit, mean temperatures of the warmest and coldest months, and mean annual temperature and precipitation were reconstructed. For the comparison with the Ferdynandów 2011 pollen diagram the data based on modern pollen analogues for the Łuków-3A pollen diagram were used.

Key words: palynostratigraphy, climatostratigraphy, plant macroremains, early Middle Pleistocene, MIS 13-15, E Poland.

\section{INTRODUCTION}

Sites documenting the Ferdynandovian pollen succession, correlated with part of the Cromerian Complex, have been rarely reported in Europe, specifically when considering the palaeobotanical record of two warm periods and the separating cooling. The division into two interglacials within the Ferdynandovian succession is consistent with the interpretation of the diagram from Ferdynandów proposed by Zagwijn (1996), who concluded that the two distinguished optima are most likely separate interglacials even if the separating cold unit was not a period of extreme climatic conditions. The matters concerning the nature of the Ferdynandovian pollen succession are raised in the discussion and have already been the subject of detailed discussion in Pidek and Małek (2010) based on the Łuków-3A profile (south Podlasie region, eastern Poland). In this context, the south Podlasie region, covering eight sites with sediments

\footnotetext{
* Corresponding author, e-mail: r.stachowicz@botany.pl Received: July 11, 2016; accepted: February 7, 2017; first published online: March 21, 2017
}

of the Ferdynandovian Interglacial identified with palynological studies (Żarski et al., 2005, 2009a), is particularly worthy of note. This area also includes the stratotype profile of Ferdynandów B (Figs. 1 and 2) drilled in 1963 (Janczyk-Kopikowa, 1963) and in 1981, described in terms of a new pollen sequence, referred to as the Ferdynandovian succession (Janczyk-Kopikowa et al., 1981; Mojski, 1985; Janczyk-Kopikowa, 1991; Rzechowski, 1996). Studies of the Ferdynandów B profile carried out by Janczyk-Kopikowa (1975) covered not only pollen, but also plant macroremains, and prior to the report of macroflora from Łuków-3A (Stachowicz-Rybka, 2015a) it remained the only example of Ferdynandovian macroflora described from Poland. Other sites in the south Podlasie region documenting this succession include Zdany and Łuków-3A. High-resolution pollen diagrams plotted for these profiles enabled a detailed reconstruction of not only their palynostratigraphy and vegetational history, but also climatic changes on a regional scale (Pidek, 2000, 2003, 2013; Pidek and Małek, 2010; Pidek and Poska, 2013). Considering the long duration of the Ferdynandovian climatostratigraphic unit, according to recent stratigraphic charts covering MIS 13-15, i.e. ca. $140 \mathrm{ka}$ of the Middle Pleistocene (Lindner et al., 2004; Cohen and Gibbard, 2011), the high-resolution palynological data from the above-mentioned sites support the view proposed by 


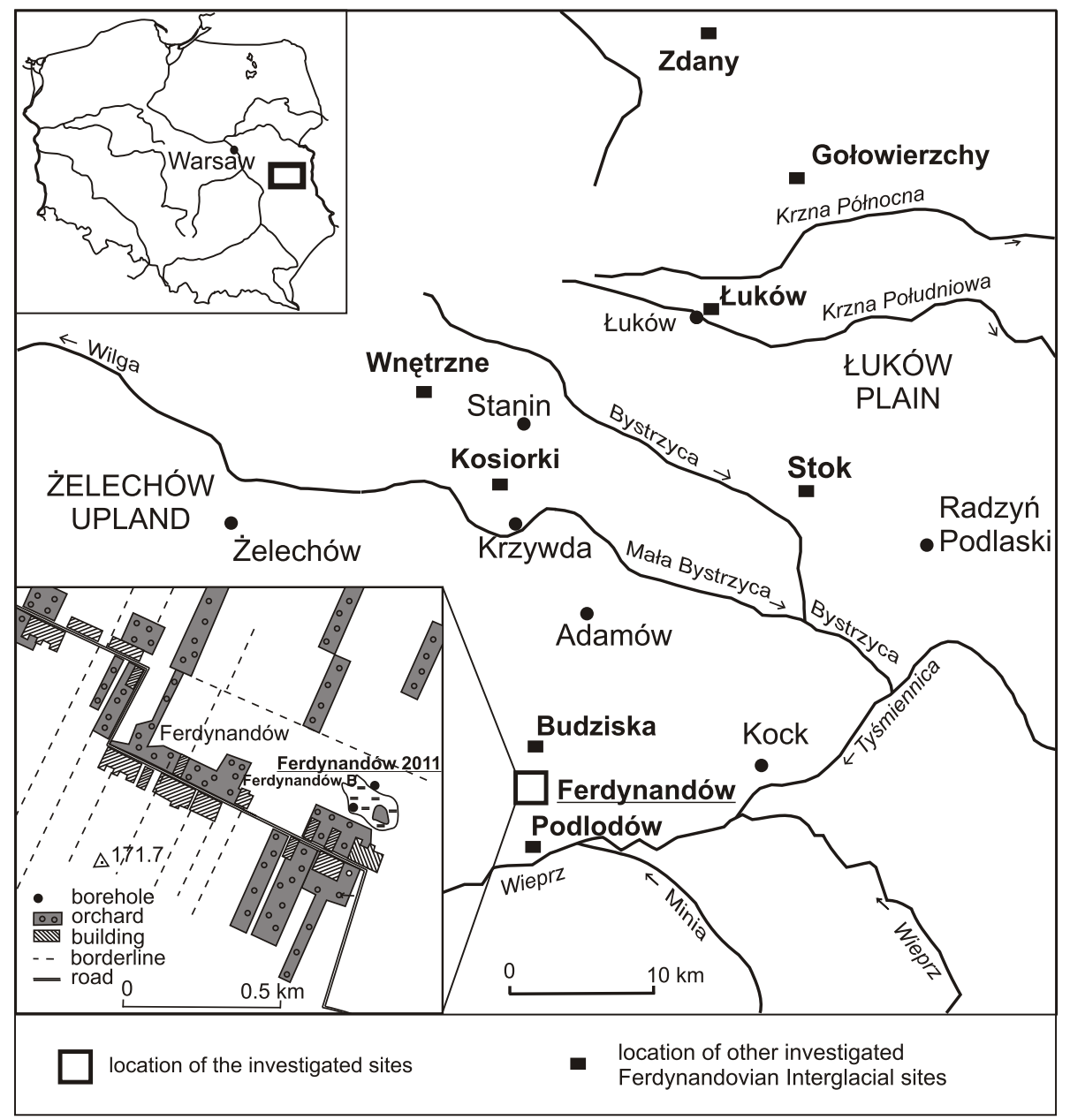

Fig. 1. Location of the investigated sites

Mamakowa (1996), who distinguished two complete interglacial successions (MIS 13 and MIS 15) and the separating cooling/glaciation (MIS 14) in the Ferdynandovian pollen succession. In Polish climatostratigraphy, the two warm units were referred to as Ferdynandovian 1 (F1) and Ferdynandovian 2 (F2), while the cooling as Ferdynandovian 1/2 (Lindner et al., 2004; Winter, 2006).

Ferdynandów B, drilled in 1963 and serving as a stratotype for the succession, included a nearly $20 \mathrm{~m}$ thick layer of lacustrine sediments, however, the profile has not been subjected to palaeobotanical examination at high-resolution, therefore conclusions on its palaeoclimate, particularly the cold period F1/2 (MIS 14), could not be drawn. Repeated drilling, carried out in 2011 and hence named Ferdynandów 2011 (Figs. 1 and 2), enabled new palaeobotanical studies and full correlation of the phases of vegetation development distinguished by Janczyk-Kopikowa

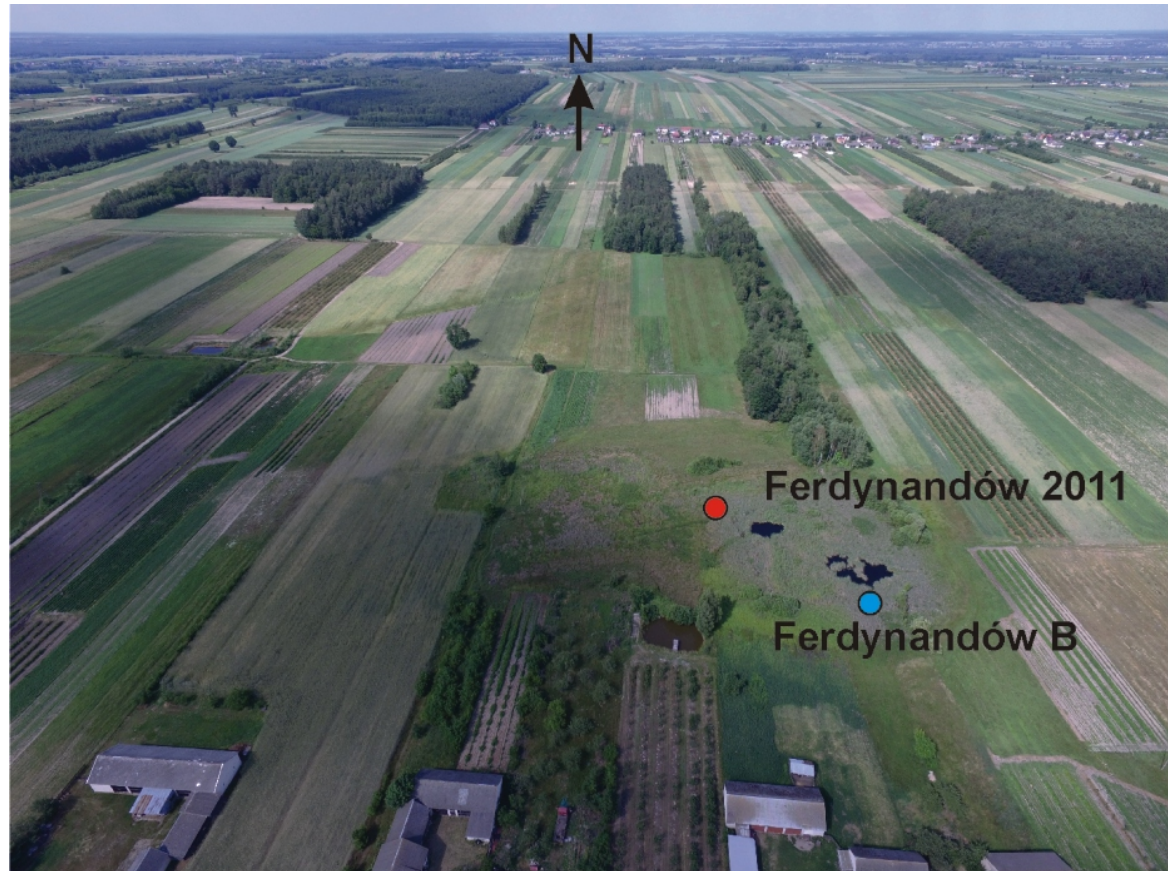

Fig. 2. Location of the Ferdynandów 2011 and Ferdynandów B profiles (photo by W. Żarski) 
(1975) with the new division of the Ferdynandovian succession (Mamakowa, 1996, 2003; Pidek, 2003) and pollen assemblage zones observed in the high-resolution pollen diagram from the adjacent site of Łuków-3A (Pidek, 2015). Moreover, palaeobotanical (palynological and plant macroremains) analyses, correlated with results of lithological studies of sediments in the Ferdynandów 2011 profile, provided important information on the development (evolution) and trophy of the palaeolake itself (Pidek et al., 2015; Stachowicz-Rybka, 2015b).

The importance of long series of lacustrine sediments, assigned to the Cromerian, in palaeoenvironment and palaeoclimate interpretations has been already emphasized, (e.g., by Rzechowski, 1996; Turner, 1996; Zagwijn, 1996). The stratotype site of Ferdynandów is of particular significance. The present study aimed to describe climate changes in MIS 13-15, concluded from the correlation of results of the high-resolution palynological and plant macroremains analyses and their comparison with climate reconstruction based on modern pollen analogues from Łuków-3A, adjacent to Ferdynandów and showing a very similar succession (Pidek and Poska, 2013).

\section{NEW LITHOLOGICAL PROFILE OF FERDYNANDÓW 2011 - GEOLOGICAL AND GEOMORPHOLOGICAL SETTING, LITHOSTRATIGRAPHY AND RECONSTRUCTION OF THE PALAEOLAKE}

Ferdynandów 2011 was drilled close to the Ferdynandów B, within an area presently forming an oval, $300 \mathrm{~m}$ long and up to $200 \mathrm{~m}$ wide endorheic depression partly filled with water and situated on a denuded plain of postglacial upland, ca. $170 \mathrm{~m}$ a.s.I. in elevation. The landform is diversified by small river valleys, dunes and, slightly farther, by single end and dead-ice moraines, eskers and kames (Żarski, 2007, 2008). Tills of the Odranian Glaciation (MIS 6; Lindner and Marks, 2012) and, slightly farther, fluvioglacial sands and gravels as well as local ice-dammed lake silts and clays are exposed on the surface around the depression. The study area was also covered by the South Polish (Narevian, Nidanian and Sanian 1 and 2) glaciations.

Middle Pleistocene sediments, attaining a thickness of several tens of metres on average and up to $100 \mathrm{~m}$ locally, overlie a basement of Upper Maastrichtian, Lower Paleocene, Eocene, Oligocene and Miocene deposits (Żarski et al., 2009b). The $55.5 \mathrm{~m}$ thick Ferdynandów 2011 section (Fig. 3) is very similar to that of Ferdynandów $B$, thoroughly investigated in terms of geology and palynology (Rzechowski, 1996). The profile Ferdynandów 2011 was described in detail by Pidek et al. (2015). Ferdynandovian lacustrine sediments are underlain by a till layer correlated with the Sanian 1 (= Elsterian 1) Glaciation (MIS 16). The $6.75 \mathrm{~m}$ thick (depth of 37.60-44.35 m; Fig. 3) lacustrine Ferdynandovian series comprises the following sequence of sediments: silts, non-calcareous gyttjas, shaly gyttjas, shales, silts with calcium carbonate precipitates, shaly silts, and strongly compressed peats. Peats are overlain by organic and laminated silts, $3.5 \mathrm{~m}$ in thickness (depth 34.1-37.6 m), assigned to the Sanian 2 (= Elsterian 2) Glaciation (MIS 12) based on palynological analysis. These sediments are covered successively by ice-dammed lake sands and silts $(2 \mathrm{~m})$, fluvioglacial sands and gravels $(4 \mathrm{~m})$, tills and loamy gravels $(5 \mathrm{~m})$, fluvioglacial sands and gravels $(2 \mathrm{~m})$, ice-dammed lake silty sands $(6 \mathrm{~m})$, and fluvioglacial gravels $(1 \mathrm{~m})$. The series of Sanian 2 sediments ends at a depth of $13.8 \mathrm{~m}$. The gravels are covered

\section{Ferdynandów 2011}
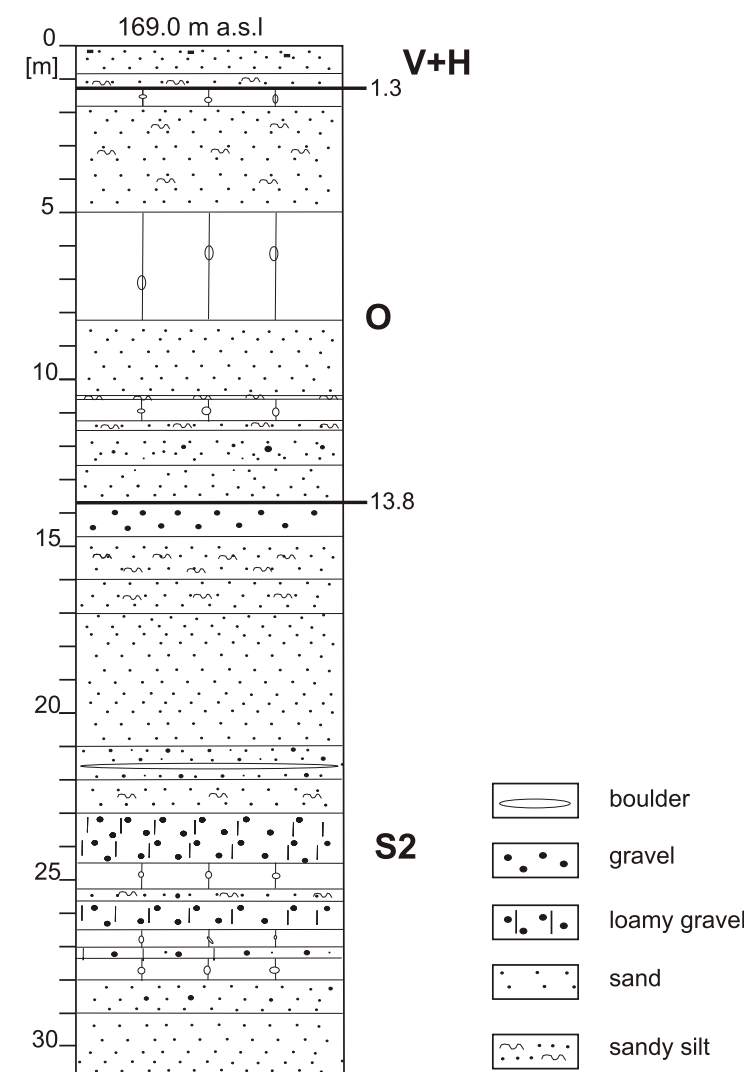

3

$30-$

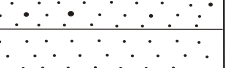

$\because \dot{\sim} \cdot$ silty sand

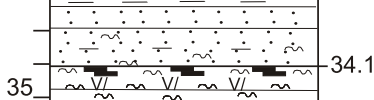

$\sim n^{n}$ silt

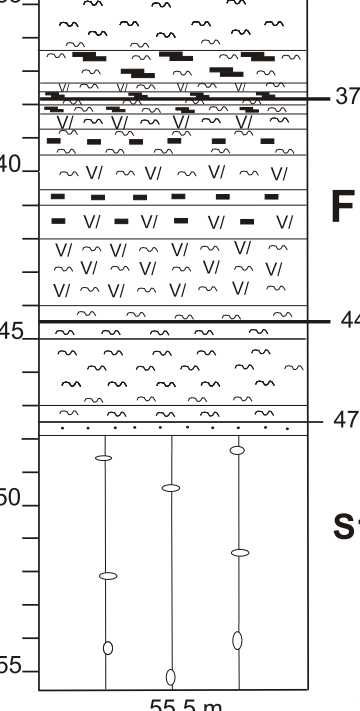

_ clay

$\square$ shale

$\simeq \simeq$ shaly silt

$\mathbf{F}$

VI $\sim v / \sim$ shaly gyttja

44.35

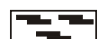

peat

$v / \sim v / \sim$ gyttja

glacial till

S1

S1 Sanian 1 Glaciation

$\mathrm{F} \quad$ Ferdynandovian Interglacial

S2 Sanian 2 Glaciation

O Odranian Glaciation

$\mathrm{V}+\mathrm{H}$ Vistulian Glaciation and Holocene

Fig. 3. Lithological section of Ferdynandów 2011

by ice-dammed lake silty sands of the Odranian Glaciation (MIS 6 ), overlain by fluvioglacial sands and gravels, a thin till layer, and another layer of fluvioglacial sands and gravels. The compact till layer attains a thickness of $3.2 \mathrm{~m}$ and is covered by $0.5 \mathrm{~m}$ thick ice-dammed lake sands and loams that terminate the sequence of Odranian sediments. The next, $0.9 \mathrm{~m}$ thick se- 
ries of diluvial sands is correlated with the Vistulian Glaciation (MIS 5d-2) and covered by soil with a $0.4 \mathrm{~m}$ thick humic horizon, which developed in the Holocene (MIS 1).

As indicated in the reconstruction of the Ferdynandów fossil lake, the basin was formed after the disappearance of the Sanian 1 ice sheet (Pidek et al., 2015), however, the origin of the palaeolake still seems ambiguous. Five boreholes were drilled within the area of the fossil basin presently covered by a peat bog. At its peripheries, three other drillings were performed. Development of the palaeolake began after the ice sheet retreat, with a formation of a flow-through basin limited on the north by the ice sheet margin and being the site of deposition of fine-grained and silty sands, up to $25 \mathrm{~m}$ in thickness. After being filled with sediments, the basin was affected by short-term water erosion in which sandy sediments were reduced, giving rise to an up to $30 \mathrm{~m}$ deep lake. Its margins were composed of tills and sands from the flow-through basin. In the cataglacial phase of the Sanian 1 Glaciation, under a very cold climate, laminated silts were accumulated in the lake. Climate warming resulted in accumulation of black silts and, subsequently, olive gyttjas. The climatic optimum of F1 was the time of deposition of grey shaly gyttjas, while the post-optimal period of olive shaly gyttjas. The palynologically documented climate change in F1/2 did not affect the type of accumulated sediment represented by olive shales overlain by shaly gyttjas, therefore it can be concluded that climate deterioration was most likely only short-term and did not result in ice sheet transgression (Pidek et al., 2015). Deposition of grey and dark grey silts followed by peats coincides with the palynologically documented strong climate warming in F2. The occurrence of peats indicates that the entire basin became shallow and overgrown by peat-forming plants. During the next glacial cooling, marked by accumulation of dark grey shales, clayey silts and olive gyttjas, the basin was refilled with water. In arctic climate conditions, ice-dammed lake mineral sediments were deposited in the Ferdynandów Basin. Its functioning ended with the accumulation of fluvioglacial sands and gravels and the eventual glacial advance.

\section{PALAEOBOTANICAL STUDIES}

\section{METHODS}

Pollen analysis. The palynological investigation was performed on a series of organogenic deposits from Ferdynandów 2011 found at a depth of 34.15-46.70 m. For purposes of this study, samples were taken at intervals ranging between $2 \mathrm{~cm}$ (in places with very high frequency of changes in pollen spectra) and $20 \mathrm{~cm}$ (in places with similar features of pollen spectra) to study the complete succession. The samples were prepared according to a standard procedure applied in pollen analysis $(\mathrm{HCl}, \mathrm{KOH}, \mathrm{HF}$, Erdtman's acetolysis; Berglund and Ralska-Jasiewiczowa, 1986). In total, 132 samples were analysed, which enabled more detailed description of pollen zones in comparison with the preliminary studies based on 99 samples from a depth between 36.40 and $44.60 \mathrm{~m}$ (Pidek, 2015). The results were presented in percentage pollen diagrams (Figs. 4 and 5) plotted with Polpal software (Nalepka and Walanus, 2003). Calculations of pollen percentages were based on the pollen sum of trees and shrubs (AP) and of terrestrial herbs and dwarf shrubs (NAP). Percentages of aquatic and reedswamp plant pollen, Pteridophyta and Bryophyta spores, and redeposited sporomorphs were calculated in relation to the sum of
$\mathrm{AP}+\mathrm{NAP}+$ examined taxa. Pollen diagrams (Figs. 4 and 5) were divided into local pollen assemblage zones based on criteria published by West (1970) and Janczyk-Kopikowa (1987). Description of the main features of pollen spectra in the new profile from Ferdynandów was provided in Pidek (2015).

Plant macrofossil analysis. Ninety-nine samples from a depth interval of 34.15-47.95 m were analysed in the Ferdynandów profile.

The samples (120-150 $\mathrm{cm}^{3}$ of sediment each) were macerated with $10 \% \mathrm{KOH}$, boiled to pulp, and wet-sieved on a $\varphi$ $0.2 \mathrm{~mm}$ sieve. Material remaining on the sieve was sorted under a stereoscopic microscope. Conservation of plant remains was done with a standard mixture of alcohol, water and glycerin $(1: 1: 1)$ with addition of thymol. Fragments of plants were then dried with $50 \%$ ethyl alcohol. Macrofossils were identified with the use of plant keys, atlases (Kats et al., 1965; Berggren, 1969; Cappers et al., 2006; Velichkevich and Zastawniak, 2006 , 2008), other scientific descriptions and publications, the reference collection of recent seeds, fruits and wood, and a collection of fossil floras housed in the Palaeobotanical Museum of the Władysław Szafer Institute of Botany, Polish Academy of Sciences, Cracow. Names of vascular plants follow mainly Mirek et al. (2002). Qualitative and quantitative results were presented in diagrams plotted with the Polpal software (Nalepka and Walanus, 2003).

\section{RESULTS}

Results of palaeobotanical identification presented in the diagrams (Figs. 4 and 5) are organized by the life form (trees, shrubs, herbaceous plants and dwarf shrubs). Aquatic and swamp plants were distinguished as a separate group to simplify comparisons with plant macroremains. In total, 22 local pollen assemblage zones (LPAZs) were determined.

In the diagram of macroscopic plant remains from Ferdynandów 2011, particular taxa were assigned to habitat groups in the order of appearance. Local macrofossil assemblage zones (LMAZs) were distinguished, numbered from base to top, and labelled from Fe-1 to Fe-11 (Fig. 6). Detailed description of the LMAZs was provided in Stachowicz-Rybka (2015b).

In both LPAZ and LMAZ diagrams, the zones were distinguished on the basis of occurrence of one or several most abundant, characteristic or diagnostic taxa. Zone boundaries were determined on the basis of appearance, disappearance, strong increase or decrease in the number of taxa having a significant quantitative or indicative value. Table 1 shows reconstructions of temperature and precipitation totals for LPAZs and L MAZs with respect to the basin development stages, and their assignment to climatostratigraphic units, following the division by Lindner et al. (2004). It is presented in chronostratigraphic order: Late Sanian 2 Glaciation, Ferdynandovian succession, including its first warm period (Ferdynandovian 1), cooling/glaciation (F1/2) and the second warm period (Ferdynandovian 2), and finally the Early Sanian 1 Glaciation.

Results of palaeobotanical studies and their palaeoclimate interpretation were discussed in accordance with the above-listed climatostratigraphic units.

\section{LATE SANIAN 1 GLACIATION}

The composition of palynological samples and pollen spectra of Fe 1 LPAZ, dominated by Artemisia, Poaceae and 


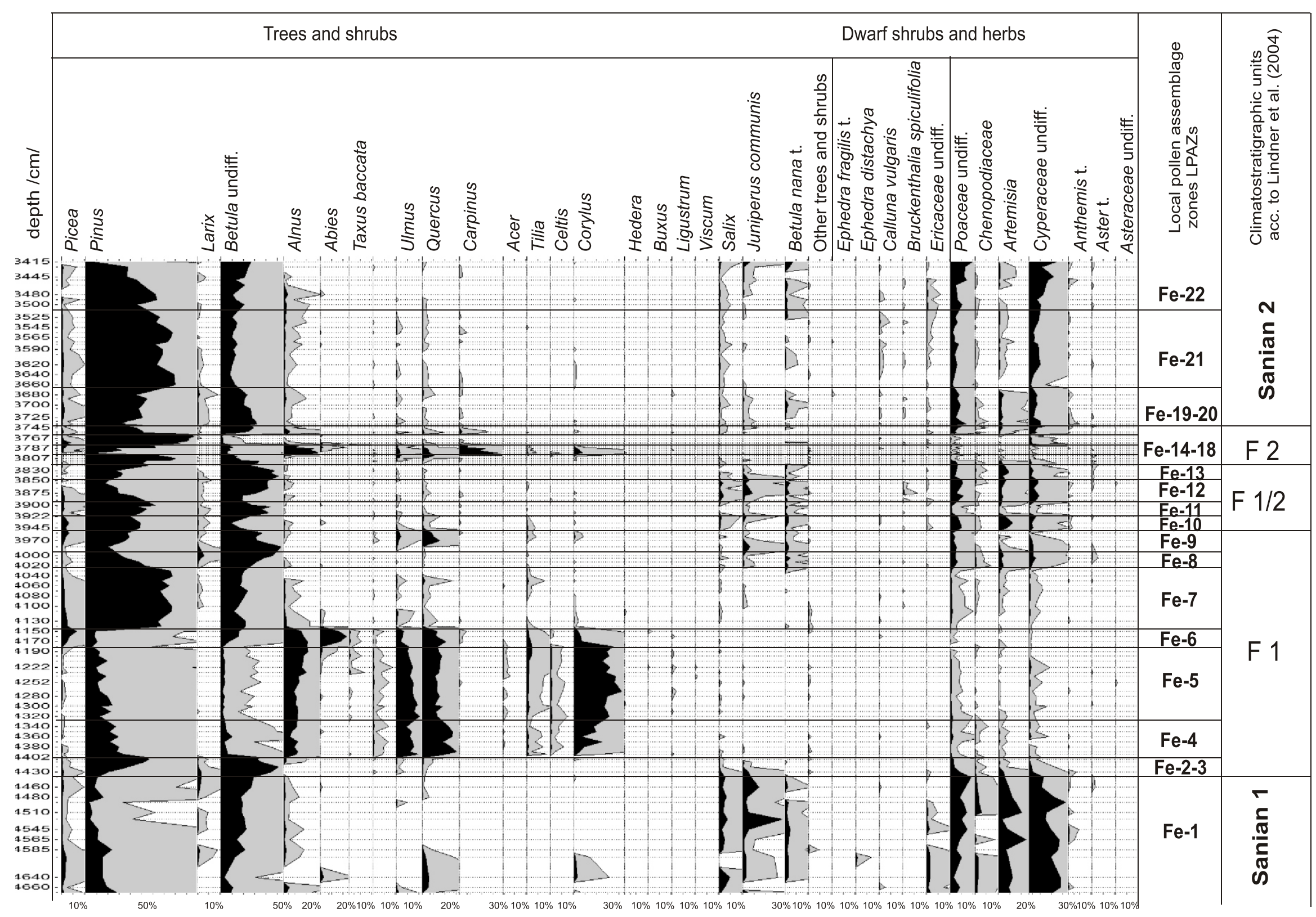

Fig. 4. Pollen diagram plotted for the Ferdynandów 2011 profile (part 1) 


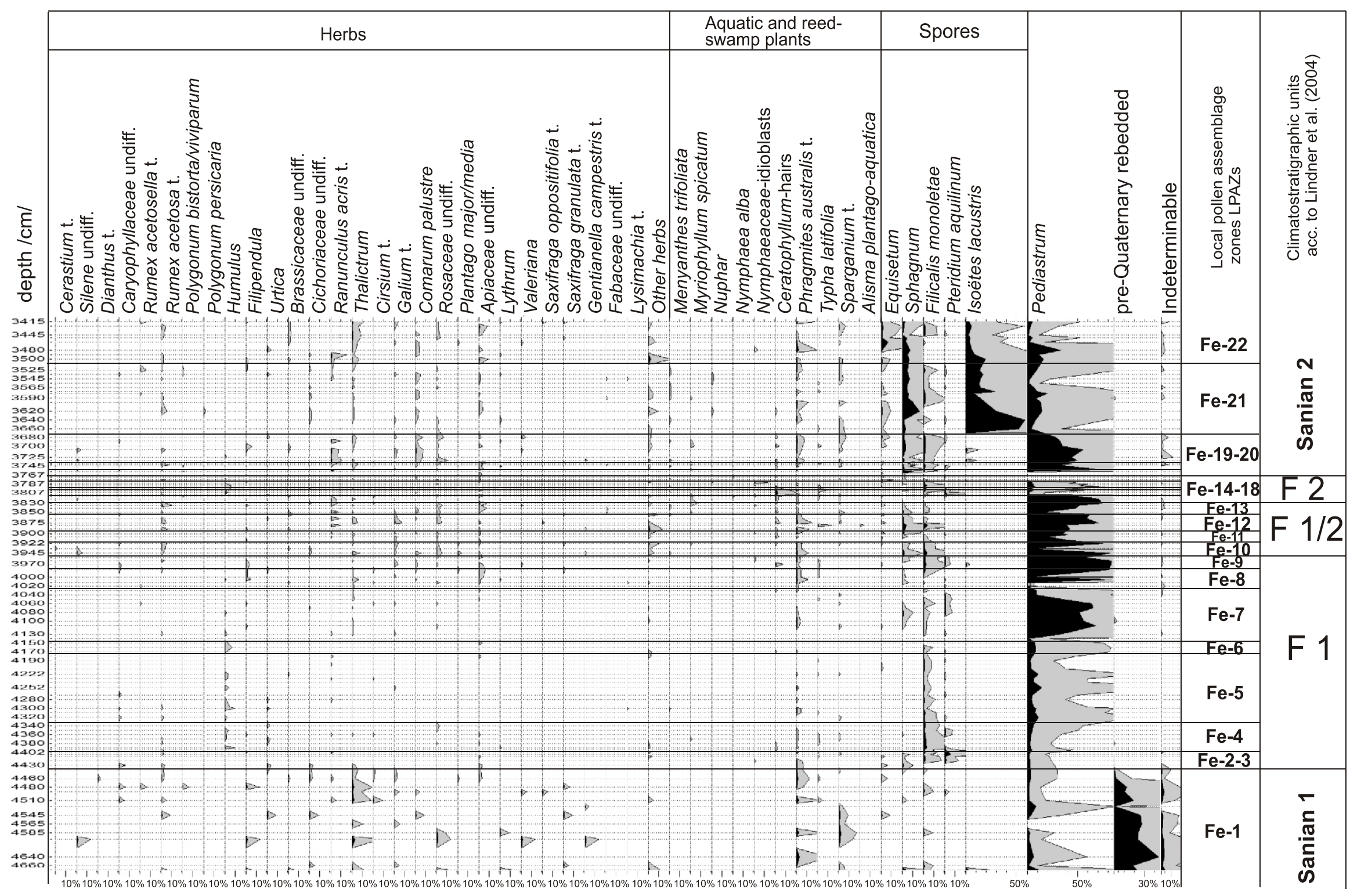

Fig. 5. Pollen diagram plotted for the Ferdynandów 2011 profile (part 2) 


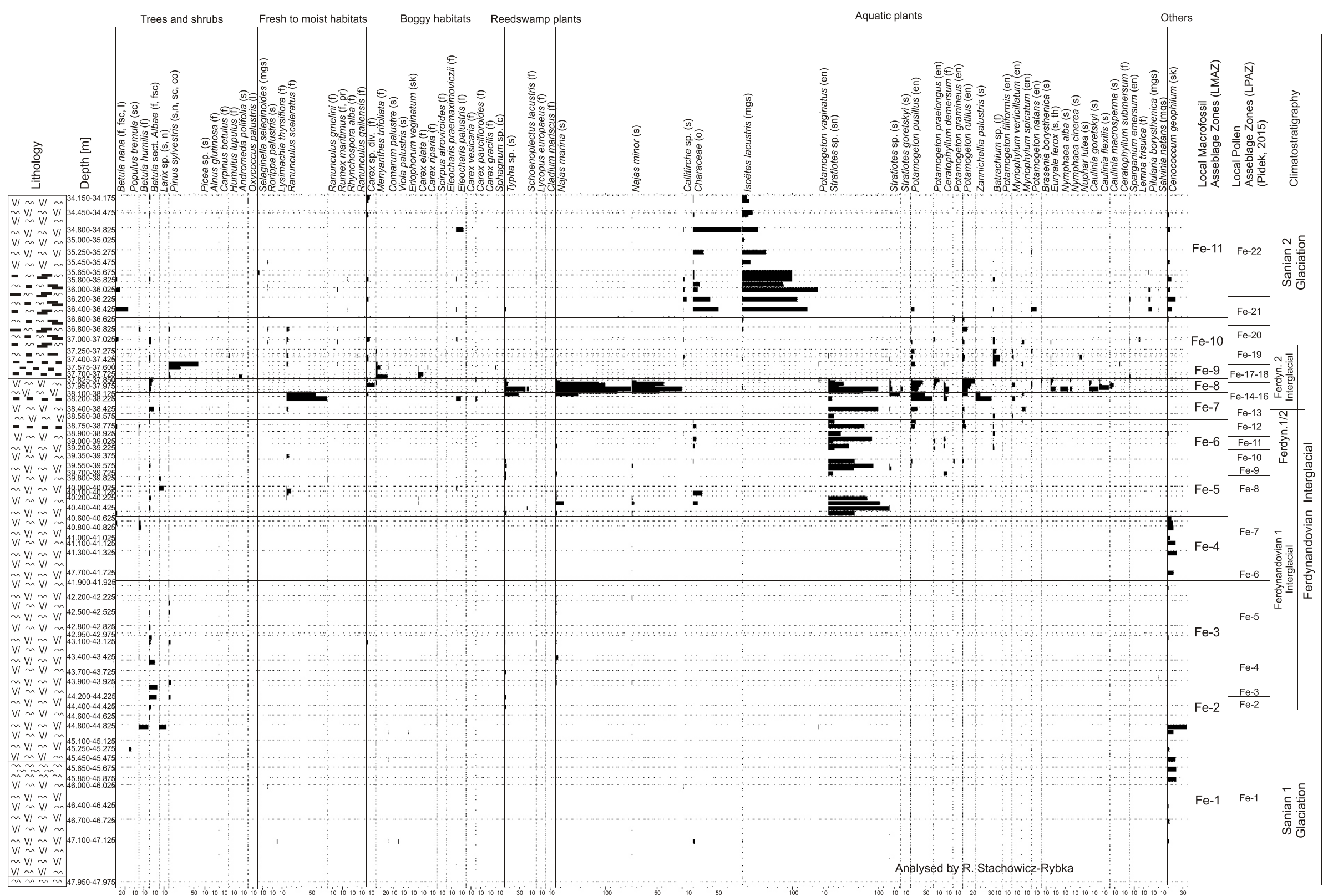

Fig. 6. Diagram plotted for plant macrofossils from the Ferdynandów 2011 profile

co - cone, en - endocarp, $f$ - fruit, fsc - fruit scale, mgs - megaspore, $n$ - needle, o - oospore, s - seed, sc - bud scale, sh - shoot, sk - sclerotia, sn - spine, st - statoblast, th - thorn 
Reconstructed climate data for LPAZs and LMAZs in the individual climatostratigraphic units

\begin{tabular}{|c|c|c|c|c|c|}
\hline \multicolumn{2}{|c|}{$\begin{array}{l}\text { Climato- } \\
\text { stratigraphic } \\
\text { units }\end{array}$} & LPAZ & LMAZ & $\begin{array}{c}\text { Corresponding } \\
\text { LPAZs in Zdany } \\
\text { and Łuków-3A } \\
\text { profiles* }\end{array}$ & Description \\
\hline \multicolumn{2}{|c|}{$\begin{array}{l}\text { Sanian } 1 \\
\text { Glaciation } \\
\text { Late Glacial }\end{array}$} & Fe 1 & Fe 1-2 & $\mid \begin{array}{l}\text { Zd1 - } \\
\text { lower part }\end{array}$ & $\begin{array}{l}\text { Very high percentages of pollen of herbaceous plants and dwarf shrubs (non-arbo- } \\
\text { real pollen =NAP); including high values of Poaceae, Cyperaceae and Artemisia, } \\
\text { frequent pollen of boreal shrubs: juniper and willow; percentages of birch pollen in- } \\
\text { crease, pine pollen percentage curve shows its long-distance origin, sporadic } \\
\text { spruce and larch pollen grains may be in situ; presence of pollen of subarctic cli- } \\
\text { mate indicators of Ephedra distachya and Betula nana t., abundant Cenococcum } \\
\text { geophilum in macrofossils, maxima of Betula humulis and Larix. Climate parame- } \\
\text { ters**: } \mathrm{T}_{\text {mann }}(-1)-(+1)^{\circ} \mathrm{C}, \mathrm{T}_{\text {mjan }}(-14)-(-10)^{\circ} \mathrm{C}, \mathrm{T}_{\text {mjul }}(+13)-(+16)^{\circ} \mathrm{C} \text {, Prec ann } \\
(450-620 \mathrm{~mm})\end{array}$ \\
\hline \multirow{3}{*}{ 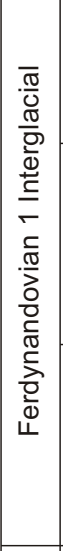 } & $\begin{array}{l}\text { F 1 } \\
\text { protocratic } \\
\text { phase }\end{array}$ & Fe 2-3 & $\begin{array}{l}\text { Fe } 2 \text { - } \\
\text { upper part }\end{array}$ & $\begin{array}{l}\text { Zd1 - upper part } \\
\text { and Łu1 }\end{array}$ & $\begin{array}{l}\text { Boreal trees (pine and birch) predominate in pollen spectra, grass and sedge } \\
\text { pollen still have high percentages, decreasing values of juniper, willow and } \\
\text { herb pollen: maxima of tree birch fruits and pine seeds in macrofossils. Climate } \\
\text { parameters: } \mathrm{T}_{\text {mann }} 0-(+5)^{\circ} \mathrm{C}, \mathrm{T}_{\text {mjan }}(-12)-(+5)^{\circ} \mathrm{C}, \mathrm{T}_{\text {mjul }}(+13)-(+16)^{\circ} \mathrm{C}, \mathrm{Prec}_{\text {ann }} \\
(450-620 \mathrm{~mm})\end{array}$ \\
\hline & $\begin{array}{l}\text { F } 1 \\
\text { optimum }\end{array}$ & Fe 4-6 & $\begin{array}{l}\text { Fe } 3 \\
\text { Fe } 4- \\
\text { lower part }\end{array}$ & $\begin{array}{l}\text { Zd2 } \\
\text { and Łu2- Łu4 }\end{array}$ & $\begin{array}{l}\text { Thermophilous trees predominate, maxima of elm and oak pollen values are } \\
\text { followed by hazel maximum; high percentages of alder, fir and lime pollen; indi- } \\
\text { cators of warm and humid climate are present: Celtis, Buxus, Hedera, } \\
\text { Ligustrum and Viscum; poor macrofossil assemblages resulting from a great } \\
\text { depth of the lake; presence of Najas marina and } N \text {. minor is noticeable. Climate } \\
\text { parameters: } \mathrm{T}_{\text {mann }} 8-(+9)^{\circ} \mathrm{C}, \mathrm{T}_{\text {mjan }}(+1.5)-(+3)^{\circ} \mathrm{C}, \mathrm{T}_{\text {mjul }}(+16)-(+18)^{\circ} \mathrm{C} \text {, Prec } \text { Prnn }_{\text {an }} \\
(800-900 \mathrm{~mm})\end{array}$ \\
\hline & $\begin{array}{l}\text { F } 1 \\
\text { termino- } \\
\text { cratic phase }\end{array}$ & Fe 7-9 & $\begin{array}{l}\text { Fe } 4- \\
\text { middle and } \\
\text { upper parts } \\
\text { Fe } 5\end{array}$ & Zd3 and Łu5 & $\begin{array}{l}\text { Boreal trees (mainly pine) predominate, spruce accounts for small admixture in } \\
\text { pollen spectra, decreasing values of all deciduous trees; presence of pollen of } \\
\text { climate indicator taxa are conspicuous: Betula nana t. and Typha latifolia; } \\
\text { seeds of Stratiotes sp. and Typha sp. as well as fruits of Schoenoplectus } \\
\text { lacustris, Ranunculus sceleratus and Urtica are present in macrofossil assem- } \\
\text { blages. Climate parameters: } \mathrm{T}_{\text {mann }} 0-(+3)^{\circ} \mathrm{C}, \mathrm{T}_{\text {mjan }}(-16)-\left(-10^{\circ} \mathrm{C}\right), \mathrm{T}_{\text {mjul }} \\
(+14)-(+16)^{\circ} \mathrm{C} \text {, Prec } \text { Prnn }_{\text {and }}(450-500 \mathrm{~mm})\end{array}$ \\
\hline \multirow{3}{*}{ 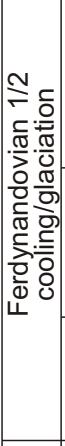 } & $\begin{array}{l}\text { F 1/2 first } \\
\text { stadial }\end{array}$ & Fe 10 & $\begin{array}{l}\text { Fe } 6 \text { - } \\
\text { lower part }\end{array}$ & \multirow{3}{*}{$\begin{array}{l}\text { Zd4- lower part } \\
\text { and Łu6 - lower } \\
\text { part } \\
\text { Zd4 and Łu6 - } \\
\text { middle parts } \\
\text { Zd4 upper part } \\
\text { and Łu6 upper } \\
\text { part and Łu7 - } \\
\text { lower part }\end{array}$} & $\begin{array}{l}\text { Herb and dwarf shrub pollen predominate (including Poaceae, Cyperaceae } \\
\text { and Artemisia which attain very high values), frequent pollen of willow, juniper } \\
\text { and larch; pollen of indicator taxa is present, such as Betula nana t. and } \\
\text { Bruckenthalia cf. spiculifolia, Oospores of Characeae are noticeable in } \\
\text { macrofossils, along with endocarps of Stratiotes sp. Climate parameters: } T_{\text {mann }} \\
(+2)-(+4)^{\circ} \mathrm{C}, \mathrm{T}_{\text {mjan }}(-17)-(15)^{\circ} \mathrm{C}, \mathrm{T}_{\text {mjul }}(+14)-(+17)^{\circ} \mathrm{C} \text {, Prec }{ }_{\text {ann }}(420-450 \mathrm{~mm})\end{array}$ \\
\hline & F $1 / 2$ & $\begin{array}{l}\mathrm{Fe} \\
11-12\end{array}$ & $\begin{array}{l}\text { Fe } 6- \\
\text { middle and } \\
\text { upper parts }\end{array}$ & & $\begin{array}{l}\text { Pinus pollen percentages increase to over } 60 \% \text {, NAP decreases to several } \\
\text { percent, rich macrofossil spectra contain numerous endocarps of } \\
\text { Potamogeton pusillus, frequent Zannichellia palustris and seeds of } \\
\text { Ranunculus sceleratus. Climate parameters: } \mathrm{T}_{\text {mann }}(-1)-(+1)^{\circ} \mathrm{C}, \mathrm{T}_{\text {mjan }} \\
(-15)-(-12)^{\circ} \mathrm{C}, \mathrm{T}_{\text {mjul }}(+16)-(+17)^{\circ} \mathrm{C} \text {, } \text { Prec }_{\text {ann }}(420-600 \mathrm{~mm})\end{array}$ \\
\hline & $\begin{array}{l}\text { F 1/2 sec- } \\
\text { ond stadial }\end{array}$ & Fe 13 & $\begin{array}{l}\text { Fe } 7 \text { - } \\
\text { lower part }\end{array}$ & & $\begin{array}{l}\text { NAP predominates, including Poaceae, Cyperaceae and Artemisia up to ca. } \\
8 \% \text { each, frequent pollen of Salix, Juniperus, Larix and Chenopodiaceae. Cli- } \\
\text { mate parameters: } \mathrm{T}_{\text {mann }} \sim 0^{\circ} \mathrm{C}, \mathrm{T}_{\text {mjan }}(-12)-(-8)^{\circ} \mathrm{C}, \mathrm{T}_{\text {mjul }}(+14)-(+16)^{\circ} \mathrm{C} \text {, Prec } \text { ann }_{\text {an }} \\
(\sim 500 \mathrm{~mm})\end{array}$ \\
\hline \multirow{3}{*}{ 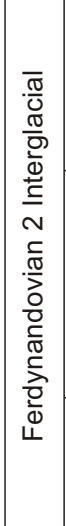 } & $\begin{array}{l}\text { F } 2 \\
\text { protocratic } \\
\text { phase }\end{array}$ & $\begin{array}{l}\mathrm{Fe} \\
14-15\end{array}$ & $\begin{array}{l}\text { Fe } 7 \text { - } \\
\text { upper part }\end{array}$ & $\begin{array}{l}\text { Zd5, Łu7 - upper } \\
\text { part, Łu8 - lower } \\
\text { part }\end{array}$ & $\begin{array}{l}\text { Pine pollen predominates up to } 70-80 \% \text {, continuous pollen curves of Ulmus } \\
\text { and Quercus appear, sharp decrease in NAP values; indicators of warm cli- } \\
\text { mate are abundant in macrofossils, such as Ceratophyllum demersum, } \\
\text { Stratiotes sp., Najas minor, } N \text {. marina and Carex paucifloroides. Climate pa- } \\
\text { rameters: } \mathrm{T}_{\text {mann }} 0-(+3)^{\circ} \mathrm{C}, \mathrm{T}_{\text {mjan }}(-17)-(-3)^{\circ} \mathrm{C}, \mathrm{T}_{\text {mjul }}(+14)-(+18)^{\circ} \mathrm{C} \text {, Prec }{ }_{\text {ann }} \\
(450-600 \mathrm{~mm})\end{array}$ \\
\hline & $\begin{array}{l}\text { F } 2 \\
\text { optimum }\end{array}$ & Fe 16 & $\begin{array}{l}\text { Fe } 8 \text { - } \\
\text { lower part }\end{array}$ & $\begin{array}{l}\text { Zd6 - lower part } \\
\text { and Łu8 - upper } \\
\text { part }\end{array}$ & $\begin{array}{l}\text { Pollen of theromophilous trees dominate, very sharp rise and maximum per- } \\
\text { centages of Carpinus (up to } 36 \%) \text {, Ulmus and Quercus maxima up to } 4 \text { and } \\
10 \% \text {, respectively; Corylus pollen up to } 8 \% \text {, Alnus rises to above } 20 \% \text {, Tilia pol- } \\
\text { len is frequent, Abies and Picea continuous pollen curves appear in the upper } \\
\text { part of the zone; maximum of macrofossils of warm and humid climate indica- } \\
\text { tors, including Brasenia borysthenica, Euryale ferox, Najas marina, } N \text {. minor } \\
\text { Caulinia macrosperma and } \mathrm{C} \text {. goretskyi. Climate parameters: } \mathrm{T}_{\text {man }} 8^{\circ} \mathrm{C} \text {, } \mathrm{T}_{\text {mjan }} \\
(-2)-0^{\circ} \mathrm{C}, \mathrm{T}_{\text {mjul }}(+18)-(+19)^{\circ} \mathrm{C} \text {, Prec } \text { Prnn }_{\text {and }}(600-800 \mathrm{~mm})\end{array}$ \\
\hline & $\begin{array}{l}\text { F } 2 \\
\text { termino- } \\
\text { cratic phase }\end{array}$ & $\begin{array}{l}\mathrm{Fe} \\
17-18\end{array}$ & $\begin{array}{l}\text { Fe } 8- \\
\text { upper part } \\
\text { Fe } 9- \\
\text { lower part }\end{array}$ & $\begin{array}{l}\text { Zd6 - upper part } \\
\text { and Łu9 }\end{array}$ & $\begin{array}{l}\text { Pollen of Pinus up to } 80 \% \text {, Picea is frequent, continuous pollen curve of Larix } \\
\text { starts again, very low values of NAP. Climate parameters: } \mathrm{T}_{\text {mann }} 0-(+3)^{\circ} \mathrm{C}, \mathrm{T}_{\text {mjan }} \\
(-17)-(-3)^{\circ} \mathrm{C}, \mathrm{T}_{\text {mjul }}(+14)-(+18)^{\circ} \mathrm{C}, \mathrm{Prec}_{\text {ann }}(450-600 \mathrm{~mm})\end{array}$ \\
\hline
\end{tabular}

* - LPAZs in Zdany and Łuków-3A profiles according to Pidek (2015);

** - climate parameters according to Pidek and Poska (2013) 
Tab. 1 cont

\begin{tabular}{|c|c|c|c|c|c|}
\hline \multicolumn{2}{|c|}{$\begin{array}{l}\text { Climato- } \\
\text { stratigraphic } \\
\text { units }\end{array}$} & LPAZ & LMAZ & $\begin{array}{l}\text { Corresponding } \\
\text { LPAZs in Zdany } \\
\text { and Łuków-3A } \\
\text { profiles }^{*}\end{array}$ & Description \\
\hline \multirow{3}{*}{ 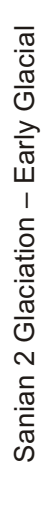 } & first stadial & $\begin{array}{l}\mathrm{Fe} \\
19-20\end{array}$ & $\begin{array}{l}\text { Fe } 9- \\
\text { upper part } \\
\text { Fe } 10- \\
\text { lower and } \\
\text { middle part }\end{array}$ & $\begin{array}{l}\text { Zd7 - lower part } \\
\text { and Łu10 }\end{array}$ & $\begin{array}{l}\text { NAP rises distinctly again, including mainly Poaceae and Cyperaceae; Artemi- } \\
\text { sia and Chenopodiaceae are frequent; pollen of indicators of cold climate are } \\
\text { conspicuous: Betula nana t., Ephedra fragilis t. and Bruckenthalia spiculifolia; } \\
\text { Betula nana, Potamogeton rutilus, P. pusillus and Batrachium sp. are present } \\
\text { among macrofossil climate indicators taxa. Climate parameters: Tmann } \\
(-1)-(+1)^{\circ} \mathrm{C}, \mathrm{T}_{\text {mjan }}(-18)-(-17)^{\circ} \mathrm{C}, \mathrm{T}_{\text {mjul }}(+16)-\left(+17^{\circ} \mathrm{C}\right), \text { Prec } \\
\left(\begin{array}{l}\text { ann } \\
(420-450 \mathrm{~mm})\end{array}\right.\end{array}$ \\
\hline & interstadial & Fe 21 & $\begin{array}{l}\text { Fe } 10- \\
\text { upper part } \\
\text { Fe } 11- \\
\text { lower part }\end{array}$ & $\begin{array}{l}\text { Zd7 - upper part } \\
\text { and Łu11 }\end{array}$ & $\begin{array}{l}\text { Pinus pollen values increase sharply up to } 80 \% \text {, frequent Picea, Larix and Alnus } \\
\text { pollen, numerous Ericaceae, percentages of NAP decrease; presence of cli- } \\
\text { mate indicator taxa: Betula nana t. and Typha latifolia; numerous spores and } \\
\text { macrofossils of Isoetes lacustris are noticeable. Presence of Pilularia } \\
\text { borysthenica. Climate parameters: } \mathrm{T}_{\text {mann }}(-1)-(+1)^{\circ} \mathrm{C}, \mathrm{T}_{\text {mjan }}(-13)-(-10)^{\circ} \mathrm{C}, \mathrm{T}_{\text {mjul }} \\
(+14)-(+15)^{\circ} \mathrm{C} \text {, Prec } \mathrm{P}_{\text {ann }}(450-600 \mathrm{~mm})\end{array}$ \\
\hline & $\begin{array}{l}\text { second } \\
\text { stadial }\end{array}$ & Fe 22 & $\begin{array}{l}\text { Fe } 11- \\
\text { middle and } \\
\text { upper part }\end{array}$ & Zd8-9 & $\begin{array}{l}\text { Percentages of NAP rise sharply upwards in the zone, especially those of Poaceae } \\
\text { and Cyperaceae; Ericaceae undiff., Artemisia and Thalictrum are frequent pollen } \\
\text { types, values of Pinus decrease, Picea, Larix, Alnus, Salix and Juniperus are fre- } \\
\text { quent; falling percentages of Isoetes lacustris macrofossil and spores, but they are } \\
\text { still frequent. Climate parameters: T } \\
(+13)-(+15)^{\circ} \mathrm{C} \text {, Prec } \text { Prec }_{\text {ann }}(420-900 \mathrm{~mm})\end{array}$ \\
\hline
\end{tabular}

* - LPAZs in Zdany and Łuków-3A profiles according to Pidek (2015);

** - climate parameters according to Pidek and Poska (2013)

Cyperaceae, accompanied by a high number of Juniperus, Salix and Betula nana t., is typical for glacial periods. Additionally, the exposed unstable bedrock was the source of numerous redeposited sporomorphs (Fig. 4), including Neogene taxa and thermophilous taxa common for the Neogene and Quaternary (e.g., Quercus, Ulmus and Corylus).

The composition of macroscopic remains in Fe 1-2 L MAZs corresponds to pollen data very well. Only single macroremains of taxa characteristic of boreal climate were observed, such as Betula nana, Selaginella selaginoides, Potamogeton vaginatus and the heliophilous Rorippa palustris. Their presence indicates open landscape and cool climate conditions. Surroundings of the basin supported development of plant communities in which peat vegetation, represented by remains of Carex sp., Menyanthes trifoliata, Comarum palustre, Viola palustris and numerous stems of brown mosses, was accompanied by Betula nana and $B$. humilis, typical of dwarf shrub tundra. Seeds and needles of Pinus sylvestris and Larix sp. confirm the at least occasional appearance of pine and larch in communities. The composition of aquatic vegetation also suggests its initial stage of development. Fruits of Potamogeton vaginatus and $P$. natans were determined, which are presently found in aquatic communities of poor-component oligotrophic waters (Matuszkiewicz, 2008).

\section{FIRST WARM PERIOD (FERDYNANDOVIAN 1)}

The beginning of the first warm period (F1) is recorded in pollen spectra of Fe 2-3 LPAZs, showing development of open boreal birch and pine-birch forests in the protocratic phase of the interglacial. Additionally, the presence of tree birch in the surroundings of the basin is confirmed by macroremains of Betula sect. Albae (Fig. 5). Subsequent palynological zones (Fe 4-5 LPAZs) are dominated by pollen of trees with much higher temperature requirements, such as Quercus, Ulmus, Fraxinus, Tilia, Taxus and Acer, evidencing formation of multispecies deciduous forests during the climatic optimum of interglacial F1. The frequency of Corylus was very high as well. Worthy of note is a continuous percentage curve of Celtis in the pollen diagram. The pollen may represent Celtis australis (Janczyk-Kopikowa, 1975) which is now a Mediterranean species. This thermophilous tree is exotic to the present-day flora of Poland. This taxon and other thermophilous Mediterranean elements (Ligustrum, Buxus) that appeared in forest communities serve as indicators of warm and humid climate. Towards the decline of the optimum, forest communities started to be colonised by spruce and fir (Fe 6 LPAZ), suggesting a change towards a colder but still highly humid climate.

The terminocratic phase of the interglacial, represented by Fe 7-9 LPAZs, is marked by an increase in the content of Pinus, Betula and NAP, appearance of Larix, and presence of Betula nana t. in the pollen spectra, indicating disappearance of thermophilous trees and succession processes in forest communities, resulting from the climate cooling. As deduced from the occurrence of Typha latifolia pollen tetrads, the temperature still did not fall below $14^{\circ} \mathrm{C}$, at least in the warmest month (Iversen, 1954; Mamakowa, 1989). This part of the diagram also displays features of another short-term warming, demonstrated by the increasing amounts of Quercus and Ulmus, likely to indicate episodic spread of communities including oak and elm, which afterwards disappeared due to the proceeding cooling.

Surprisingly, remains of aquatic plants were not numerous, which is typical of large and relatively deep lakes, while ecological requirements of the determined taxa suggest warm climate. The continuous though infrequent presence of seeds of Najas marina and minor amounts of remains of Najas minor were observed. These species are most commonly found in highly insolated, sheltered spots (Tomaszewicz, 1979; Matuszkiewicz, 2008), and are the most thermophilous taxa identified within Ferdynandovian 1. Similar temperature and trophic conditions are preferred by the floating fern Salvinia natans recorded at the base of Fe-11 LMAZ and typical of warm areas of suboceanic and moderate climate as well as tropical climate (Holm et al., 1979).

The end of Ferdynandovian 1 is characterized by the reappearance of taxa typical of cool boreal climate, such as Betula humilis and $B$. nana growing in dwarf shrub tundra, and frequency of Larix sp. rose as well. Such communities most likely in- 
cluded also Ranunculus gmelini, an arctic-boreal species observed in tundra- and woody tundra-type interstadial floras, and usually overgrowing boggy areas and shores of rivers and lakes.

The terminocratic phase of the interglacial, represented by Fe 9 LPAZ (Pidek, 2015), is marked by an increase in the content of Pinus, Betula and NAP, appearance of Larix, and presence of Betula nana t. in pollen spectra, which evidences disappearance of thermophilous trees and succession processes in forest communities, resulting from the climate cooling. However, this part of the diagram also displays features of a short-term warming, demonstrated by the increasing amounts of Quercus and Ulmus, likely to indicate episodic spread of communities including these trees, which afterwards disappeared due to the proceeding cooling. The top part of $\mathrm{Fe}-5$ LMAZ, like the corresponding pollen assemblage zone (documenting an interstadial fluctuation) and the Łuków-3A profile (Stachowicz-Rybka, 2015a), does not comprise taxa suggesting an obvious climate improvement. However, it shows an increase in the number of specimens, particularly spines and seed fragments of Stratiotes sp., and Najas minor, N. marina and Scirpus atroviroides.

\section{COOLING/GLACIATION F1/2}

This period is recorded in Fe 10 LPAZ (Fig. 5) as a rapid increase in the values of Artemisia, Poaceae and other herbaceous taxa. This indicates great changes in plant communities, including expansion of plants typical for open areas, such as tundra and steppe-tundra, characteristic for a glacial cooling. Additionally, appearance of the continuous curve of Sphagnum spores suggests development of peat bogs. Another climate change within the glacial period (F1/2), observed in Fe $11 \mathrm{LPAZ}$ as dominance of Pinus and Betula, points to an interstadial fluctuation. However, it was followed by another cooling recorded as redevelopment of open plant communities, i.e. tundra and steppe-tundra, in Fe 13 LPAZ (Fig. 4). This zone ends the glacial pollen sequence separating the two warmings (F1 and F2) in the Ferdynandovian succession.

When considering macrofossil analysis, this period is represented by Fe-6 LMAZ and the basal part of Fe-7 LMAZ. It still includes taxa identified at the cool end of Ferdynandovian 1, such as Betula nana, B. humilis and Larix sp. Such a composition of trees and shrubs, as well as the appearance of herbaceous plants, e.g. Ranunculus gmelini, evidences cool climatic conditions and an important role of patches of dwarf shrub tundra-type vegetation in the landscape of lake surroundings. Increased eutrophication, demonstrated by the greater diversity of taxa with higher trophic requirements in all ecological groups, indicates that the basin gradually became shallower and overgrown. In eutrophic habitats of periodically exposed lakeshores, communities with Ranunculus sceleratus gained importance. In humid areas with lower trophy, there also appeared Rhynchospora alba, found mainly in transition bogs and humid depressions of raised bogs. Single fruits of Schoenoplectus lacustris and Typha sp. may have originated from communities resembling the present-day Scirpo-Phragmitetum swamps (Podbielkowski and Tomaszewicz, 1982); however, not being an important component of landscape in this case. Scirpo-Phragmitetum typicum Wheeler, 1980 includes oligotrophic and species-poor swamps and reed beds in which Phragmites is the sole constant. The reed cover can be open or closed, but Phragmites is always the most abundant helophyte forming a canopy from about 1 to $3 \mathrm{~m}$ high. Other species can, however, be locally prominent including other swamp dominants such as Typha latifolia, $T$. angustifolia, Schoenoplectus lacustris and Rhynchospora alba. Among aquatic plants, Potamogeton praelongus, $P$. gramineus, $P$. pusillus and $P$. rutilus were identified.

Cool, clear, and calcium carbonate-rich lake water was inhabited by Characeae, indicating the presence of stonewort meadows typical of waters up to $10 \mathrm{~m}$ in depth (Hannon and Gaillard, 1997). Such water level, as well as pH of ca. 7.8, is also supported by the occurrence of Ceratophyllum demersum (Gaillard and Birks, 2007). Zannichellia palustris, known to prefer habitats of variable water level, appeared as well.

\section{SECOND WARM PERIOD (FERDYNANDOVIAN 2)}

The beginning of the second warm period of interglacial rank (F2) is documented in pollen assemblage zone Fe-14 showing a rapid increase in Pinus values, indicating reexpansion of boreal pine forests. It was followed by the appearance of thermophilous deciduous trees and shrubs, such as Quercus, UImus and Corylus, and spread of bog alder forests, as evidenced by the high frequency of Alnus, most likely accompanied by Picea and, perhaps at later stages, also by Abies. The climatic optimum of this warming is best recorded in Fe 16 LPAZ, obviously dominated by Carpinus. The surroundings of Ferdynandów were recolonized by deciduous forests, namely oak-hornbeam forests with numerous hazel and admixture of lime.

However, the strong rise in the Pinus pollen curve and higher frequency of Picea pollen in Fe 17-18 LPAZs point to another cooling. These zones represent the terminocratic phase of the second interglacial (F2), in which thermophilous trees disappeared and were replaced by pine forests. Habitats of higher humidity supported spruce communities.

Fe-8 LMAZ bears a record of the final phase of overgrowing of the eutrophic basin, additionally affected by advantageous climatic conditions, and therefore marked by remarkably intense development of aquatic, swamp and peat vegetation. Sediment of this period is exceptionally abundant in diaspores, displaying the greatest taxonomic diversity. Shallow, warm waters were inhabited by Brasenia borysthenica, a component of the so-called Brasenia-complex. The term widely used by Velichkevich and Zastawniak (2008) means the association of thermophilous water plants with predominance of Brasenia, which were characteristic for the optimal climatic phases of the Belovezhian and Mogilevian interglacials of Belarus and Muchkap and Ikorets analogous interglacials of western Russia (Velichkevich and Zastawniak, 2008; Yakubovskaya et al., 2014). Remains of Euryale ferox, represented by large fragments of thick-walled seeds, were also identified and compared with seeds from the Czarnucha and Żarnowo sites (Stachowicz-Rybka, 2011)

The composition of aquatic vegetation changed significantly and became dominated by Najas marina that preferred highly insolated, sheltered spots in lakes (Tomaszewicz, 1979; Matuszkiewicz, 2008). The species most likely formed underwater fields also with abundant Najas minor, presently often growing in dense communities, which can as well form monocultures found in highly eutrophic habitats, on muddy or muddy-sandy bottoms at a depth of $\sim 0.5-2 \mathrm{~m}$ (Wentz and Stuckey, 1971). In communities of macrohydrophytes, usually rooted, the dominant Najas marina and $N$. minor were most likely accompanied by extinct Caulinia macrosperma, C. goretskyi and Brasenia borysthenica. In other communities, macrophytes included also numerous Potamogeton spp.

Fe-9 LMAZ bears a record of the end of the warm Ferdynandovian 2, when the lake-to-peat bog transition entered its final phase. Taxa typical of transition bogs became more 
abundant and were represented mainly by remains of Menyanthes trifoliata, Comarum palustre, Carex elata, C. riparia, and C. vesicaria, stems of brown mosses, remains of Sphagnum sp., seeds of Andromeda polifolia, and leaves of Vaccinum sp. Tall sedge communities most likely formed a belt adjacent to the basin shores. In the terminocratic phase of Ferdynandovian 2 , features of terrestrial vegetation already indicated the upcoming cooling, as manifested by the reappearance of nutlets of Betula nana and $B$. humilis in sediment as well as by the high content of pollen of Pinus sylvestris and Betula undiff. in Fe 17-18 LPAZs. However, simultaneously, aquatic vegetation was still abundant within thermophilous taxa. The swamp zone and deep waters were inhabited by macrophytes, including Najas marina, Ceratophyllum demersum, C. submersum and Nuphar sp. Such an observation is typical to the ends of interglacials, when the waters of lakes cool down at a lower rate than the surrounding land and therefore for a longer time serve as a warm habitat for plant development.

\section{EARLY SANIAN 2 GLACIATION}

A next glacial sequence, recognized as the Early Sanian 2 Glaciation, begins with Fe 19 LPAZ. It is marked by stadial-interstadial fluctuations recorded in four pollen assemblage zones (Fe 19-22 LPAZs; Fig. 4). Zones representing stadials (Fe 19-20 LPAZs and Fe 22 LPAZ) display variable percentages of taxa associated with tundra and steppe-tundra communities (Artemisia, Poaceae, Cyperaceae, Chenopodiaceae, Betula nana t., and Juniperus), while the zone documenting the first interstadial of the Sanian 2 Glaciation (Fe 21 LPAZ) is dominated by Pinus.

The Early Sanian 2 Glaciation is recorded in the top part of Fe-9 LMAZ and in Fe-10-11 LMAZs. The zones comprise sediments of acidic peats and coarse detritus gyttjas, developed in a cool, oligotrophic lake. Deterioration of climatic conditions resulted in the reappearance of species characteristic for a tundra landscape in the lake surroundings, such as Betula nana, Selaginella selaginoides and Rorippa palustris. In Fe-10 LMAZ, however, remains of Larix sp. and Pinus sylvestris were accompanied by fruits of taxa with higher temperature requirements, e.g. Carpinus betulus and Humulus lupulus, the presence of which should be linked to stadial-interstadial fluctuations. The presence of these two species in the deposits cannot be the proof of their occurrence in the forest at that time. In the cold climate conditions, the process of redeposition of older deposits can result in mixed micro- and macrofossil assemblages with both boreal and more warm-loving species. In Fe 19-22 LPAZs, representing stadials, pollen values for taxa associated with tundra and steppe-tundra communities were also variable. Fe-10 LMAZ records disappearance of aquatic vegetation and arrival of peat plant associations in the palaeolake, which indicates terrestrialisation of the basin, no longer filled with open water. In this period of the Early Sanian 2 Glaciation, the discussed depression was covered with a peat bog including numerous Carex sp. div., C. elata, C. rostrata, Menyanthes trifoliata, Scirpus atroviroides, S. sylvaticus, Eleocharis palustris, E. ovata and Caltha palustris.

Remains of aquatic plants reappeared abundantly only in the last sediment sample of the zone. They included mainly endocarps of Potamogeton spp., accompanied by seeds of Callitriche autumnalis, fruits of Batrachium sp., Ceratophyllum demersum, Myriophyllum verticillatum and $M$. spicatum, seed fragments and spines of Euryale ferox, as well as remains of Nuphar lutea and Sparganium emersum. Such a taxonomic composition suggests a strong rise in the water level of peat bog and re-occurrence of a water basin, initially inhabited by similar taxa as the ones recorded in Fe-9 LMAZ (Fig. 6).

Macroremains found in Fe-11 LMAZ show that the water basin of Ferdynandów was surrounded by rather open pine-birch forests, as evidenced by seed scales and leaves of Betula nana and nutlets of Betula sect. Albae and $B$. humilis as well as by the high curve of Pinus sylvestris in Fe 21 LPAZ. The basin waters were colonised by taxa from an association resembling modern Isoëto-Lobelietum, with Isoëtes lacustris as a characteristic species. This sciophyte presently grows in oligotrophic water basins, pine forests and acidophilous mixed coniferous forests. The Isoëto-Lobelietum association usually develops in oligo- and mesotrophic lakes with sandy or sandy-rocky bottoms. Patches of Isoëtes lacustris cover deeper (ca. $2 \mathrm{~m}$ deep) parts of lakes. The species serves as an indicator of relatively cool and nutrient-poor waters. These results were confirmed by the spore-pollen spectra for Fe 20-22 LPAZs, where Isoëtes spores were recorded abundantly.

Changes in climatic conditions and the proceeding acidification of soils altered the structure of vegetation in the basin surroundings. A transition bog began its functioning. Diversity of local taxa increased, as recorded in Fe-11 LMAZ. Remains of several sedge species and Andromeda polifolia, leaves of Oxycoccus palustris, Rhynchospora alba and Vaccinum sp., as well as seeds and nodes of Eriophorum vaginatum and Comarum palustre were identified. However, hydrological conditions of the peat bog were still unstable, as indicated by the variable proportions of pine and birch, capable of expanding to the peat bog area, on the one hand, and by the appearance of species requiring greater humidity, such as Oenanthe aquatica, Carex pseudocyperus, Lycopus europaeus and Lysimachia thyrsiflora, on the other hand. This pattern suggests a change in hydrogeological conditions and transition of the Sphagnum bog to a raised bog.

\section{DISCUSSION}

The Ferdynandovian pollen sequence and its division have been established in recent years due to detailed investigations of this pollen succession. New pollen data enabled obtaining higher resolution of vegetation and climate changes based on 132 pollen samples and 99 plant macrofossil samples. They revealed the complete Ferdynandovian s.l. succession with adjoining glacial units of Sanian 1 and Sanian 2. These two separate interglacials in the Ferdynandovian pollen succession correspond with the interpretation of the pollen diagram from the Ferdynandów B site by Zagwijn (1996) and with the opinion by Turner (1996). Both the authors related the Ferdynandovian sequence to the Cromerian complex (Zagwijn, 1996; Turner, 1996). When referring to the West European stratigraphy, Zagwijn (1996) correlated the F1 (=lower warm period) from Ferdynandów B with the Cromerian II (Westerhoven), and the F2 (=upper interglacial) with the Cromerian III (Rosmalen). Lindner et al. (2004) and Ber et al. (2007) were of the opinion that unit $\mathrm{F} 1$ of the Ferdynandovian sequence should be related to the Cromerian III, and the F2 to the Cromerian IV (Noordbergum). Detailed correlation with the West European stratigraphy has not been possible due to fragmentary nature of pollen data. Ferdynandovian Interglacial corresponding with palaeosols correlates in Western Europe with the Cromerian II, III and IV warming episodes of the Netherlands (e.g., Andersen, 1965; Zagwijn, 1996, 1996; Turner, 1996), and with warmings 
preceding the Elsterian 2 (Sanian 2) Glaciation in Germany (Erd, 1978; Grüger, 1996; Hahne, 1996).

Based on similarities in the pollen successions from the three neighbouring sites (Ferdynandów 2011, Zdany and Łuków-3A) more conclusions can be drawn about climatic conditions during the MIS 13-15.

Two interglacials of the Ferdynandovian pollen succession, F1 (correlated to MIS 15) and F2 (correlated to MIS 13), differ in the characteristics of their climatic optima. The major difference is the amount of Carpinus, spreading in F2 and in F1, recorded only as single pollen grains at the final phases of the interglacial. Moreover, the beginning of $\mathrm{F} 1$ is marked by extensive spread of riverine communities dominated by Ulmus. These main differences may have resulted from the very humid climate of $\mathrm{F} 1$, additionally confirmed by the presence of plant indicators such as Hedera, Ilex and Celtis, not observed in F2.

Nevertheless, both interglacials recorded in the pollen succession of Ferdynandów 2011 show palaeoclimate conditions highly consistent with those reconstructed for the profiles Łuków-3A and Zdany. All three palaeolakes (Ferdynandów 2011, Łuków-3A and Zdany) included Typha latifolia, indicating warm summers with a mean July temperature ( $T_{\text {mjul }}$ of at least $14^{\circ} \mathrm{C}$ (Iversen, 1954; Mamakowa, 1989) already at the close of the Sanian 1 Glaciation. The palaeotemperature reconstruction was based on modern pollen analogues. The modern pollen analogue method uses a modern pollen database in which pollen spectra are associated with corresponding climatological data (Guiot et al., 1993). The modern analogue database, used by Pidek and Poska (2013), included 1107 surface pollen spectra and corresponding climate data ranging from 137 to $2259 \mathrm{~mm}$ of precipitation totals and a mean annual temperature between -12 and $20^{\circ} \mathrm{C}$. The spectra were collected in Europe and Asia and gathered as a database by Guiot et al. (1993). The programme PPPbase by Guiot matches the best fitting analogue to each fossil pollen spectrum (Guiot and Goeury,1996).

\section{INTERGLACIAL F1}

The reconstruction points to temperatures varying between $+16^{\circ} \mathrm{C} \mathrm{T}_{\text {mjul }}$ and $-14^{\circ} \mathrm{C} \mathrm{T}_{\text {mjan }}$ at the beginning of interglacial $\mathrm{F} 1$ (Pidek and Poska, 2013). Climate humidity is supported by the reconstruction for Zdany, which suggests total annual precipitation (Prec $\mathrm{ann}_{\mathrm{an}}$ ) of 450-620 mm during the Late Glacial, rapidly increasing to $800-900 \mathrm{~mm}$ at the beginning of F1 (Pidek and Poska, 2013).

Based on the method of pollen indicators of climate conditions, the early spread of Ulmus also allows estimation of the mean July temperature to at least $16^{\circ} \mathrm{C}$ (Granoszewski, 2003). The very sharp increase of the mean annual temperature at the beginning of interglacial $F 1$ is in consistence with results obtained by Krzyszkowski et al. (1996). According to Iversen (1944), the presence of Hedera, Ilex and Viscum indicates a mean January temperature not falling below $-1.5^{\circ} \mathrm{C}$ (Hedera) and a mean July temperature of at least $+17^{\circ} \mathrm{C}$ (Viscum).

The occurrence of the most thermophilous taxa identified by the plant macroremains analysis shows that the temperature of the warmest month in the optimum of $\mathrm{F} 1$ ranged from $+18^{\circ} \mathrm{C}$ $\mathrm{T}_{\text {mjul }}$ (Najas minor) to $+15^{\circ} \mathrm{C} \mathrm{T}_{\text {mjul }}$ (Najas marina) (Aalbersberg and Litt, 1998). The presence of Salvinia natans, recorded at the base of Fe-11 LMAZ, which is typical of warm areas of suboceanic moderate and tropical climates (Holm et al., 1979), seems particularly interesting. The species inhabits mainly eutrophic waters of large or shallow and slow-flowing rivers, oxbow lakes, ditches and channels (Casper and Krausch, 1980). For the development of its megaspores, it requires tempera- tures of winter months not falling below $0^{\circ} \mathrm{C}$ (Święta-Musznicka et al., 2011).

The close of interglacial F1 is marked by a decrease in the number of temperate trees and shrubs and disappearance of plant indicators of warm climate. Palaeoclimate reconstructions, based on the Łuków-3A and Zdany profiles, suggest increased seasonality reflected by temperatures falling to $\sim+16^{\circ} \mathrm{C}$ $\mathrm{T}_{\text {mjul }}$ and below $-10^{\circ} \mathrm{C} \mathrm{T}_{\text {mjan }}$. Simultaneously, total annual precipitation decreased to $\sim 500 \mathrm{~mm}$. These observations coincide with plant macrofossil finds, including taxa characteristic for cool, boreal climate, such as Betula humilis, B. nana and Ranunculus gmelini.

\section{COOLING/GLACIATION F1/2}

The two stadials of F1/2 cooling/glaciation are marked by the presence of cold steppe taxa and heliophytes (Ephedra, Artemisia, Chenopodiaceae). They provide strong evidence of greater climate seasonality and aridity, and therefore continentality. Aquatic plants also included species typical to Late Glacial periods and their cool climate. The presence of Potamogeton praelongus and $P$. gramineus, requiring a minimum July temperature of $+8^{\circ} \mathrm{C}$ (Kolstrup, 1980; Gaillard, 1984), is of particular importance.

Data from Ferdynandów 2011 are consistent with palaeoclimate reconstructions of unit $F 1 / 2$ for the Łuków-3A and Zdany profiles, showing a decrease in climate parameters such as mean temperature of the coldest month to $-15^{\circ} \mathrm{C} \mathrm{T}_{\text {mian }}$ or even $-17^{\circ} \mathrm{C} \mathrm{T}_{\text {mjan }}$ and annual precipitation totals of $\sim 450 \mathrm{~mm}$ Precann. However, $\mathrm{T}_{\text {mjul }}$ still attained $\sim 14^{\circ} \mathrm{C}$, which corresponds to the occurrence of Typha latifolia in all three fossil lakes discussed.

Re-expansion of boreal pine-birch forests marks an interstadial period within the F1/2 cooling, which must have been associated with a rise in mean July temperature to $\sim 12^{\circ} \mathrm{C}$.

Palaeoclimate reconstructions for Łuków-3A and Zdany suggest conditions of ca. $-12^{\circ} \mathrm{C} \mathrm{T}_{\text {mjan, }}, \sim+14^{\circ} \mathrm{C} \mathrm{T}_{\text {mjul }}$ and $\sim 600 \mathrm{~mm}$ Prec $_{a n n}$. Additionally, the occurrence of Bruckenthalia spiculifolia and Ephedra in pollen diagrams from Zdany and Łuków-3A suggests a rather continental climate (cf. Granoszewski, 2003)

The next stadial within F1/2 is evidenced by an increase in values of herb and dwarf shrub pollen, indicating disappearance of pine-birch forests. Palaeoclimate reconstructions based on modern pollen analogues revealed a decrease in climate parameters to $\sim 510 \mathrm{~mm} \operatorname{Prec}_{\mathrm{ann}}$, below $+14^{\circ} \mathrm{C} \mathrm{T}_{\mathrm{mjul}}$ and $-10^{\circ} \mathrm{C} \mathrm{T}_{\text {mjan }}$ (Pidek and Poska, 2013).

\section{INTERGLACIAL F2}

Rapid climate changes towards the second interglacial (F2) in the Ferdynandovian pollen succession enabled development of rich multispecies forests.

Palaeoclimate reconstructions for Łuków-3A and Zdany suggest a strong increase in temperature to $-2^{\circ} \mathrm{C} \mathrm{T}_{\text {mjan }}$ (from the initial $-17^{\circ} \mathrm{C} \mathrm{T}_{\text {mian }}$ ) and $+19^{\circ} \mathrm{C} \mathrm{T}_{\text {mjul }}$, accounting for the general rise in mean annual temperature to $8^{\circ} \mathrm{C}$ and much less seasonal climate. Additionally, total annual precipitation $\left(\mathrm{Prec}_{a n n}\right)$ increased from $\sim 450$ to $\sim 800 \mathrm{~mm}$. These observations are supported by the results of plant macrofossil analysis. During F2, aquatic communities developed, including even more thermophilous plants, such as Cyperus glomeratus $\left(+20^{\circ} \mathrm{C} \mathrm{T}_{\text {mjul }}\right.$; Aalbersberg and Litt, 1998) and two extinct species of Brasenia borysthenica $\left(+20-21^{\circ} \mathrm{C} \mathrm{T}_{\text {mjul }}\right.$ estimated for B. schreberi; Tobolski, 1991) and 
Aldrovanda borysthenica $\left(+18^{\circ} \mathrm{C} \mathrm{T}_{\text {miul }}\right.$ estimated for $A$. vesiculosa; Aalbersberg and Litt, 1998). Among aquatic plants, the presence of Euryale ferox is worthy of note. Modern Euryale ferox can be found in tropical and subtropical zones of south-east Asia, where mean July temperatures attain $21^{\circ} \mathrm{C}$. In this case, we obviously have to assume that extinct species had similar ecological tolerances to extant ones.

The presence of Trapa natans and Salvinia natans at the close of interglacial F2 in the lake basin of Łuków-3A (Pidek and Poska, 2013) should be emphasized, as it may suggest that the lake water was still eutrophic and warm. This can be consistent with estimations of the mean July temperature $\left(18^{\circ} \mathrm{C}\right)$ for this site.

\section{SANIAN 2 GLACIATION}

Another glacial period resulted in the transition of boreal forests to forest-tundra and subarctic tundra. Palaeoclimate reconstructions for Łuków-3A and Zdany show a significant decrease in climate parameters to $-18^{\circ} \mathrm{C} \mathrm{T}_{\text {mjan }}, 0^{\circ} \mathrm{C} \mathrm{T}_{\text {mann }}$, and $\sim 420 \mathrm{~mm}$ Prec $_{\text {ann }}$.

In the pollen diagram of Ferdynandów 2011, the first interstadial is marked by a sharp increase in pine values, indicating that tundra and mire communities were partly replaced by boreal forests, therefore the mean July temperature most likely exceeded $12^{\circ} \mathrm{C}$ at that time. Winters were probably very cold. Palaeoclimate reconstructions for Łuków-3A and Zdany suggest fluctuations of the mean January temperature between -13 and $-10^{\circ} \mathrm{C}$.

In terms of plant macroremains, the interstadial of the Early Sanian 2 Glaciation was typified by the occurrence of Myriophyllum spicatum, M. verticillatum and Eleocharis palustris, serving as indicators of $+10^{\circ} \mathrm{C} \mathrm{T}_{\text {mjul }}$ (Aalbersberg and Litt, 1998), similarly as Hippuris vulgaris (Wasylikowa, 1964). The presence of Potamogeton praelongus points to $+8^{\circ} \mathrm{C} \mathrm{T}_{\text {mjul }}$ (Kolstrup, 1980).

\section{CONCLUSIONS}

High-resolution palynological and plant macrofossil analyses of the new Ferdynandów stratotype profile (drilled in 2011) have allowed a thorough palaeoclimate interpretation and identification of climatostratigraphic units, namely the Late Sanian 1 Glaciation, Ferdynandovian 1, Ferdynandovian 1/2, Ferdynandovian 2 and Early Sanian 2 Glaciation (following Lindner et al., 2004; Winter, 2006).
Results of palaeobotanical examinations and the pollen and macrofossil assemblage zones were correlated with data obtained for profiles from the adjacent sites of the South Podlasie region. These are the Zdany and Łuków-3A sections, for which a detailed palaeoclimate reconstruction covering the mean annual temperature and precipitation, and mean temperatures of the warmest and coldest months, has already been provided based on modern pollen analogues. Results of the reconstruction complied with the available literature data on temperature and humidity requirements of plant indicators of palaeoclimate.

As indicated by the presence of the most extremely thermophilous taxa, identified by the plant macroremains analysis, the temperature of the warmest month $\left(T_{\text {mjul }}\right)$ varied between +18 and $+15^{\circ} \mathrm{C}$ during the $\mathrm{F} 1$ optimum. Palaeotemperature reconstruction that based on the modern pollen analogues method showed temperatures about $+16^{\circ} \mathrm{C} \mathrm{T}_{\text {mjul }}$ at the beginning of interglacial F1, evidenced by the appearance of Ulmus. Period F2 was a time of development of aquatic communities including many more thermophilous plants requiring temperatures varying between $+21^{\circ} \mathrm{C} \mathrm{T}_{\text {mjul }}$ and $+18^{\circ} \mathrm{C} \mathrm{T}_{\text {mjul }}$. Following the modern pollen analogues approach, the temperature of the warmest month $\left(T_{\text {mjul }}\right)$ reached $\sim 19^{\circ} \mathrm{C}$ in this period.

Therefore, the high-resolution palaeobotanical analysis of the Ferdynandów 2011 profile complements the results of archival studies of Janczyk-Kopikowa on the stratotype profile (drilled in 1963). It provides more detailed information, particularly on the period separating the two warmings, supporting the new division of the Ferdynandovian succession (following Mamakowa, 1996, 2003).

Referring the new high-resolution data from the Ferdynandów 2011 to the West European Cromerian Complex (MIS 13-15) has enabled a broader palaeogeographic interpretation of the south Podlasie region that is of key importance for investigating the location and development of a fossil lakeland functioning in this area in MIS 13-15.

Acknowledgements. We warmly thank Professor M.H. Field (Universiteit Leiden) and $\mathrm{Dr} \mathrm{J}$. Hahne (Geologischer Dienst Baden-Württemberg, Germany) for very helpful review comments and suggestions, and MSc K. Stachowicz for valuable assistance in the laboratory during sample collection and preparation. The study was financed from research grant No. NN 307039940 (2011-2015) awarded by the Ministry of Science and Higher Education, and from statutory funds of the the W. Szafer Institute of Botany, Polish Academy of Sciences, and Faculty of Earth Sciences and Spatial Management, Maria Curie-Skłodowska University.

\section{REFERENCES}

Aalbersberg, G., Litt, T., 1998. Multiproxy climate reconstructions for the Eemian and Weichselian. Journal of Quaternary Science, 13: 367-390.

Andersen, S.T., 1965. Interglacialer og interstadialer Danmarks Kvarter. Meddelelser fra Dansk Geologisk Forening, 15: 486-506.

Ber, A., Lindner, L., Marks, L., 2007. Proposal of a stratigraphic subdivision of the Quaternary of Poland (in Polish with English summary). Przegląd Geologiczny, 55: 115-118.

Berggren, G., 1969. Atlas of Seeds and Small Fruits of Northwest-European Plant Species with Morphological Descriptions.
Part 2. Cyperaceae. Swedish National Research Council, Stockholm.

Berglund, B.E., Ralska-Jasiewiczowa, M., 1986. Pollen analysis and pollen diagrams. In: Handbook of Holocene Palaeoecology and Palaeohydrology (eds. B.E. Berglund and M. Ralska-Jasiewiczowa): 455-484. J. Wiley and Sons Ltd., Chichester-Toronto.

Cappers, R.T.J., Bekker, R.M., Jans, J.E.A., 2006. Digital Seed Atlas of the Netherlands. Groningen, Barkhuis/Groningen University Library. 
Casper, S.J., Krausch, H.D., 1980. Pteridophyta und Anthophyta. Lycopodiaceae bis Orchidaceae. Gustav Fischer Verlag, Jena: 72-74.

Cohen, K.M., Gibbard, P.L., 2011. Global Chronostratigraphical Correlation Table for the Last 2.7 Milion Years. Subcommission on Quaternary Stratigraphy (International Commission on Stratigraphy), Cambridge, England, www.quaternary.stratigraphy.org.uk

Erd, K., 1978. Pollenstratigraphie im Gebiet der skandinavischen Vereisungen. Schriftenreihe für Geologische Wissenschaften, 9: $99-119$

Gaillard, M.J., 1984. A Palaeohydrological Study of Krageholmssjon (Scania, South Sweden). Regional Vegetation History and Water-level Changes. LUNDQUA Report 25.

Gaillard, M.J., Birks, H.H., 2007. Paleolimnological applications. In: Encyclopedia of Quaternary Science, 3 (ed. A.E. Scott): 2337-2356. Elsevier, Amsterdam.

Granoszewski, W., 2003. Late Pleistocene vegetation history and climatic changes at Horoszki Duże, Eastern Poland: a palaeobotanical study. Acta Palaeobotanica, Suppl., 4: 3-95.

Grüger, F., 1996. Palynostratigraphy of the Middle Pleistocene sequence from Göttingen, Otto-Strasse. In: The Early Middle Pleistocene in Europe (ed. Ch. Turner): 173-179. A.A. Balkema, Rotterdam/Brookfield.

Guiot, J., Goeury, C., 1996. PPPBASE, a software for statistical analysis of paleoecological and paleoclimatological data. Dendrochronologia, 14: 295-300.

Guiot, J., Harrison, S.P., Prentice, T.C., 1993. Reconstruction of Holocene patterns of moisture in Europe using pollen and lake-level data. Quaternary Research, 40: 139-149.

Hahne, J., 1996. The interglacial site of Hunteburg near Quakenbrück (NW Germany). In: The Early Middle Pleistocene in Europe (ed. Ch. Turner): 181-186. A.A. Balkema, Rotterdam/Brookfield.

Hannon, G.E., Gaillard, M.K., 1997. The plant macrofossil record of past lake-level changes. Journal of Paleolimnology, 18: 15-28.

Holm, L., Pancho, J.V., Herberger, J.P., Plucknett, D.L., 1979. A Geographical Atlas of World Weeds. Wiley, New York.

Iversen, J., 1944. Viscum, Hedera and Ilex as climate indicators. A contribution to the study of the Post-Glacial temperature climate. Geologiska Föreningens i Stockholm Förhandlingar, 66 : 463-483.

Iversen, J., 1954. The late-glacial flora of Denmark and its relations to climate and soils. Danmarks Geologiske Undersøgelse, 2: 87-115.

Janczyk-Kopikowa, Z., 1963. Pollen analysis of the Quaternary deposits from Ferdynandów (NW of Kock) (in Polish with English summary). Kwartalnik Geologiczny, 7 (4): 639-644.

Janczyk-Kopikowa, Z., 1975. Flora of the Mazovian Interglacial at Ferdynandów (in Polish with English summary). Biuletyn Instytutu Geologicznego, 290: 5-94.

Janczyk-Kopikowa, Z., 1987. Remarks on palynostratigraphy of the Quaternary. Kwartalnik Geologiczny, 31 (1): 155-162.

Janczyk-Kopikowa, Z., 1991. The Ferdynandów Interglacial in Poland (in Polish with English summary). Geological Quarterly, 35 (1): 71-80.

Janczyk-Kopikowa, Z., Mojski, J.E., Rzechowski, J., 1981. Position of the Ferdynandów Interglacial, Middle Poland, in the Quaternary stratigraphy of the North European Plain. Biuletyn Instytutu Geologicznego, 335: 65-79.

Kats, N.Ya., Kats, S.V., Kipiani, M.G., 1965. Atlas and keys of fruits and seeds occurring in the Quaternary deposits of the USSR (in Russian). Izdat. Nauka, Moskva.

Kolstrup, E., 1980. Climate and stratigraphy in northwestern Europe between $30.000 \mathrm{BP}$ and $13.000 \mathrm{BP}$, with special reference to the Netherlands. Haarlem: Rijks Geologische Dienst, 32/15: 181-253.

Krzyszkowski, D., Böttger, T., Junge, F.W., Kuszell, T., Nawrocki, J., 1996. Ferdynandovian Interglacial climate reconstructions from pollen successions, stable isotope composition and magnetic susceptibility. Boreas, 25: 283-296.
Lindner, L., Marks, L., 2012. Climatostratigraphic subdivision of the Pleistocene Middle Polish Complex in Poland (in Polish with English summary). Przegląd Geologiczny, 60: 36-45.

Lindner, L., Gozhik, P., Marciniak, B., Marks, L., Yelovicheva, Y., 2004. Main climatic changes in the Quaternary of Poland, Belarus and Ukraine. Geological Quarterly, 48 (2): 97-114.

Mamakowa, K., 1989. Late Middle Polish Glaciation, Eemian and Early Vistulian vegetation at Imbramowice near Wrocław and the pollen stratigraphy of this part of the Pleistocene in Poland. Acta Palaeobotanica, 29: 11-176.

Mamakowa, K., 1996. Nowe dane palinologiczne z profilu Podgórze (in Polish). Szczegółowa mapa geologiczna Polski ark. Bałobrzegi. NAG PIG, Warszawa, no. 2327/97.

Mamakowa, K., 2003. Plejstocen (in Polish). In: Palinologia (eds. S. Dybova-Jachowicz and A. Sadowska): 235-266. Wydawnictwo Naukowe PAN, Kraków.

Mojski, J.E., 1985. Quaternary. Geology of Poland, vol. I/3b. Wyd. Geol., Warszawa

Matuszkiewicz, W., 2008. Przewodnik do oznaczania zbiorowisk roślinnych Polski (in Polish). Wydawnictwo Naukowe PWN, Warszawa.

Mirek, Z., Piękoś-Mirkowa, H., Zając, A., Zając, M., 2002. Flowering plants and Pteridophytes of Poland. A checklist. W. Szafer Institute of Botany, PASc, Kraków.

Nalepka, D., Walanus, A., 2003. Data processing in pollen analysis. Acta Palaeobotanica, 43: 125-134.

Pidek, I.A., 2000. Palynostratigraphic interpretation of the cold unit between two warm ones in the Ferdynandovian succession from Zdany (eastern Poland) (in Polish with English summary). Przegląd Geologiczny, 48: 1035-1038.

Pidek, I.A., 2003. Mesopleistocene vegetation history in the Northern Foreland of the Lublin Upland based on palaeobotanical studies of the profiles from Zdany and Brus sites. Wydawnictwo UMCS, Lublin.

Pidek, I.A., 2013. Pollen-based vegetation and climate reconstruction of the Ferdynandovian sequence from Łuków (E Poland). Acta Palaeobotanica, 53: 115-138.

Pidek, I.A., 2015. Palynostratigraphy and vegetation changes during the early Middle Pleistocene, based on new studies of deposits from Ferdynandów (central eastern Poland). Acta Palaeobotanica, 55: 53-66.

Pidek, A., Małek, M., 2010. A bi-partie Ferdynandovian succession from Łuków, Eastern Poland: a new palynostratigraphic approach. Geological Quarterly, 54 (1): 69-84.

Pidek, I.A., Poska, A., 2013. Pollen based quantitative climate reconstructions from the Middle Pleistocene sequences at Łuków and Zdany (E Poland): species and modern analogues based approach. Review of Palaeobotany and Palynology, 192: 65-78.

Pidek, I.A., Stachowicz-Rybka, R., Żarski, M., 2015. Nowe dane paleobotaniczne z profilu Ferdynandów 2011 na stanowisku stratotypowym (in Polish). Annales UMCS, sect. B, 70: 9-26.

Podbielkowski, Z., Tomaszewicz, H., 1982. Zarys hydrobotaniki (in Polish). PWN, Warszawa.

Rzechowski, J., 1996. The Ferdynandowian Interglacial and its stratigraphical position in the Middle Pleistocene of Europe. In The Early Middle Pleistocene in Europe (ed. Ch. Turned): 279-293. Balkema, Rotterdam.

Stachowicz-Rybka, R., 2011. Flora and vegetation changes on the basis of plant macroremains analysis from an early Pleistocene lake of the Augustów Plain, NE Poland. Acta Palaeobotanica, 51: 39-104

Stachowicz-Rybka, R., 2015a. Record of environmental and climatic changes in middle Pleistocene sediments from Łuków (eastern Poland) on the basis of plant macroremains analysis. Acta Palaeobotanica, 55: 67-91.

Stachowicz-Rybka, R., 2015b. Vegetation of the Ferdynandovian interglacial (MIS 13-15) based on plant macrofossils from a new profile of the stratotype site. Acta Palaeobotanica, 55: 233-251.

Święta-Musznicka, J., Latałowa, M., Szmeja, J., Badura, M., 2011. Salvinia natans in medieval wetland deposits in Gdańsk, northern Poland: evidence for the early medieval climate warming. Journal of Paleolimnology, 45: 369-383. 
Tobolski, K., 1991. Eemian and Vistulian biostratigraphy of Great Poland Kujawy Lowland (in Polish with English summary). Geografia, 50: 573-583.

Tomaszewicz, H., 1979. Roślinność wodna i szuwarowa Polski (in Polish). Rozprawy Uniwersytetu Warszawskiego.

Turner, Ch., 1996. A brief survey of the early Middle Pleistocene in Europe: 295-317. In: The Early Middle Pleistocene in Europe (ed. Turner Ch). Balkema, Rotterdam.

Velichkevich, F.Yu., Zastawniak, E., 2006. Atlas of Pleistocene Vascular Plant Macroremains of Central and Eastern Europe, Part I - Pteridophytes and Monocotyledons. W. Szafer Institute of Botany, Polish Academy of Sciences, Cracow.

Velichkevich, F.Yu., Zastawniak, E., 2008. Atlas of vascular plant macroremains from the Pleistocene of central and eastern Europe, Part II - Herbaceous dicotyledons. W. Szafer Institute of Botany, Polish Academy of Sciences, Cracow.

Wasylikowa, K., 1964. Vegetation and climate of the Late Glacial in Central Poland based on investigations made at Witów near Łęczyca (in Polish with English summary). Biuletyn Peryglacjalny, 13: 261-417.

Wentz, W.A., Stuckey, R.L., 1971. The changing distribution of the genus Najas (Najadaceae) in Ohio. Ohio Journal Sciences, 71: 292-302.

West, R.G., 1970. Pollen zones in the Pleistocene of Great Britain and their correlation. New Phytologist, 69: 1179-1183.

Winter, H., 2006. Problems of Pleistocene interglacials and glaciations - general remarks (in Polish with English summary) Przegląd Geologiczny, 54: 142-144.
Yakubovskaya, T.V., Litvinyuk, G.I., Motuzko, A.H., 2014. Korchevskoye mezhlednikovye Belorussii (in Russian with English summary) Isdatiel V. Chursick, Minsk.

Zagwijn, W.H., 1996. The Cromerian Complex Stage of the Netherlands and correlation with other areas in Europe. In: Proceedings of the SEQS Cromer Symposium Norwich (United Kingdom) (ed. Ch. Turner): 145-172. 3-7 September, 1990, Balkema, Rotterdam/Brookfield.

Żarski, M., 2007. Szczegółowa Mapa Geologiczna Polski 1:50 000 ark. Okrzeja wraz z objaśnieniami (in Polish). Państwowy Instytut Geologiczny, Warszawa.

Żarski, M., 2008. Szczegółowa Mapa Geologiczna Polski 1: 50000 ark. Adamów wraz z objaśnieniami (in Polish). Państwowy Instytut Geologiczny, Warszawa.

Żarski, M., Nita, M., Winter, H., 2005. New interglacial sites in the region of the Wilga and Okrzejka river valleys at the Żelechów Upland (SE Poland) (in Polish with English summary). Przegląd Geologiczny, 52: 137-144.

Żarski, M., Małek, M., Albrycht, A., 2009a. Plejstocen południowego Podlasia (in Polish). In: XVI Konferencja Stratygrafia plejstocenu Polski. Strefa marginalna lądolodu zlodowacenia warty i pojezierza plejstoceńskie na południowym Podlasiu. Zimna Woda k. Łukowa, 31.08-4.09. 2009. Państwowy Instytut Geologiczny, Warszawa.

Żarski, M., Małek, M., Albrycht, A., 2009b. Tektonika i podłoże osadów czwartorzędowych południowego Podlasia (in Polish). In: XVI Konferencja Stratygrafia plejstocenu Polski. Strefa marginalna lądolodu zlodowacenia warty i pojezierza plejstoceńskie na południowym Podlasiu. Zimna Woda k. Łukowa, 31.08-4.09. 2009. PIG-PIB Warszawa. 